\title{
The chestnut growing hotspot of Turkey in danger: introduction of the Asian chestnut gall wasp into Aegean region
}

\author{
Melih Mıcık $^{a}$ (D), Meltem Özçankayab ${ }^{b}$, Fikriye Öçal ${ }^{b}$ (i), Kahraman İpekdal ${ }^{c, *}$ (i)
}

\begin{abstract}
Asian chestnut gall wasp, Dryocosmus kuriphilus Yasumatsu (Hymenoptera, Cynipidae), is an important pest of Castanea species worldwide. Adults emerge in summer and lay eggs in a few days. Severe infestations may reduce chestnut and timber production. It was first recorded in Europe in 2002 from Italy. In April 2014, it was recorded in Turkey for the first time in Marmara region (Yalova, north-western Turkey). Despite quarantine measures, infected chestnut saplings were sold from this region to several growers in western Turkey (Aydın and İzmir) in 2018. Although most of these saplings were removed and burned shortly after planting, some planted saplings could not be detected and some adult emergences may have occurred before the sapling removal, we had accepted hypothetically the Asian chestnut gall wasp was introduced in the region. Confirming this hypothesis, we detected the pest in a private chestnut orchard in 2020 in İzmir. Although, to date, we have not found it in adjacent natural chestnut stands, it will most probably increase in the whole region in the near future. As the largest private chestnut orchards of Turkey occur in this region, the Asian chestnut gall wasp invasion in the region will have serious socioeconomic consequences. Accordingly, we began to inform growers and foresters in the region, and to develop pest management strategies. Keywords: Dryocosmus kuriphilus, Castanea sativa, Range expansion, New record
\end{abstract}

\section{Türkiye'nin kestane üretim merkezi tehlike altında: Kestane gal arısının Ege Bölgesi'ne girişi}

\begin{abstract}
Özet: Kestane gal arısı, Dryocosmus kuriphilus Yasumatsu (Hymenoptera, Cynipidae), dünya genelinde kestane türlerinin önemli bir zararlısıdır. Erginleri yaz aylarında çıkmakta ve birkaç gün içinde yumurta bırakmaktadır. Kestane gal arısı yoğun istila durumunda kestane meyvesi ve odun üretimini azaltabilmektedir. Avrupa'daki ilk kaydı 2002 yılında İtalya'da yapılmıştır. Türkiye'de ise ilk olarak Nisan 2014'te Marmara Bölgesi'nde (Yalova) tespit edilmiştir. Karantina tedbirlerine rağmen 2018 yılında bu bölgeden Aydın ve İzmir'e, üzerinde kestane gal arısı galleri bulunan kestane fidan satışı yapılmıştır. Her ne kadar bu fidanların büyük bir kısmı, dikildikten kısa bir süre sonra imha edilmişse de, bazı fidanların tespitinin yapılamadığını ve bazı ergin çıkışlarının imhadan önce gerçekleşmiş olabileceğini göz önünde bulundurarak kestane gal arısının bu bölgeye bulaştığını varsaymıştık. Zararlıyı 2020 yılında İzmir'de tespit ederek bu varsayımı doğrulamış olduk. Zararlıyı civardaki doğal meşcerelerde tespit edememiş olsak da zararlının yakın bir gelecekte tüm bölgede artacağı söylenebilir. Özel kestanelikler bakımından Türkiye'nin en önemli bölgesi olması bakımından, ketane gal arısı istilasının bu bölgede ciddi sosyoekonomik sonuçları olacaktır. Bu nedenle bölgedeki üretici ve ormancıların bilgilendirilmesine ve mücadele stratejilerinin geliştirilmesine başlanmıştır.
\end{abstract}

Anahtar kelimeler: Dryocosmus kuriphilus, Castanea sativa, Yayılış alanı genişletme, Yeni kayıt

\section{Introduction}

Asian chestnut gall wasp, Dryocosmus kuriphilus Yasumatsu (Hymenoptera, Cynipidae), is one of the most important insect pests on Castanea (Fagaceae) species worldwide as it causes significant decrease in chestnut harvest (Battisti et al., 2013; EPPO, 2005). It is native to China but was accidentally introduced to Europe (Italy) in 2002 (Brussino et al., 2002). It was first recorded in 2014 in Turkey (Çetin et al., 2014), the center of origin of $C$. sativa (Mattoni et al., 2013; Villani et al., 1994) and one of the largest chestnut producers (fourth in the world and second in Europe) (50.000-70.000 x 10 kg/year) (FAO, 2002).
In Turkey, Asian chestnut gall wasp is currently present in several localities around Marmara region as well as along the Black Sea coast (Azmaz and Katılmış, 2020; İpekdal et al., 2014; Y1ldiz et al., 2020). The rate of dispersal speed was reported as $25 \mathrm{~km} /$ year by Graziosi and Santi (2008) in Italy and by Rieske (2007) in the USA. It is, evidently, spreading much faster in Turkey due to anthropogenic factors. We recently detected Asian chestnut gall wasp in a private chestnut orchard in İzmir province (Aegean region), which is within the largest chestnut growing area in Turkey.
Sinop Provincial Directorate of Agriculture and Forestry, Sinop, Turkey

b İzmir Regional Directorate of Forestry Department of Forest Pest Management, Karşıyaka, İzmir, Turkey

c Ahi Evran University Faculty of Agriculture, Bağbaşı Campus, Kırşehir, Turkey

@ * Corresponding author (İletişim yazarı): kipekdal@gmail.com

$\checkmark \quad$ Received (Geliş tarihi): 03.12.2020, Accepted (Kabul tarihi): 08.01.2021
Citation (Atıf): Mıcık, M., Özçankaya, M., Öçal, F., İpekdal, K., 2021. The chestnut growing hotspot of Turkey in danger: introduction of the Asian chestnut gall wasp into Aegean region. Turkish Journal of Forestry, 22(1): 62-64. DOI: $10.18182 /$ tjf. 835221 


\section{Materials and methods}

Although trade in chestnut saplings was prohibited since 2015 due to national quarantine measures, a chestnut producer from Bursa (Marmara region, north-western Turkey), the first invasion spot of the pest in Turkey, had sold a large number of saplings to growers in Aydin and İzmir (Aegean region, western Turkey) in 2017. After detecting galls on the plants sent to İzmir, they were removed and burned on site on 6 June 2017 by the local departments of forestry and agriculture. Unfortunately, as this date was in the range of adult emergence, it was quite possible that the adult gall wasps emerged (and oviposited) in this area. Unfortunately, no examination for adult emergence holes on the galls was conducted prior to destruction of the infected saplings. Furthermore, as the transfer of the saplings was an illegal activity, precise information on the customers, and therefore the location of all saplings transferred to the region, remained largely unknown. As a result, we hypothetically accepted that Asian chestnut gall wasp was present in the region and began monitoring both the stands and the orchards. Along with the national monitoring program in which range expansion of the pest is recorded annually, we conducted field surveys between 2018 and 2020 particularly in the İzmir locality where extensive sapling destruction was carried out in 2017.

\section{Results}

We recorded D. kuriphilus galls on chestnut shoots for the first time from a private orchard (38.043108 ${ }^{\circ}$ North latitude, $28.114492^{\circ}$ East longitude) on 16 July 2020 in Ödemiş, İzmir, Turkey (Figure 1, 2). Gall density was relatively low (2-3 galls per $50 \mathrm{~cm}$ of twig, one twig per tree, and one tree in ten trees). We detected the Asian chestnut gall wasp only in this private orchard but not in other orchards or adjacent natural stands. Additionally, the closest occurrence of the pest to this orchard was approximately $180 \mathrm{~km}$ away. This finding suggests anthropogenic transfer of the pest to the region, which confirms the hypothesis that illegal transport of infested chestnut saplings to the region in 2017 caused the infestation, despite the destruction of saplings following gall detection.
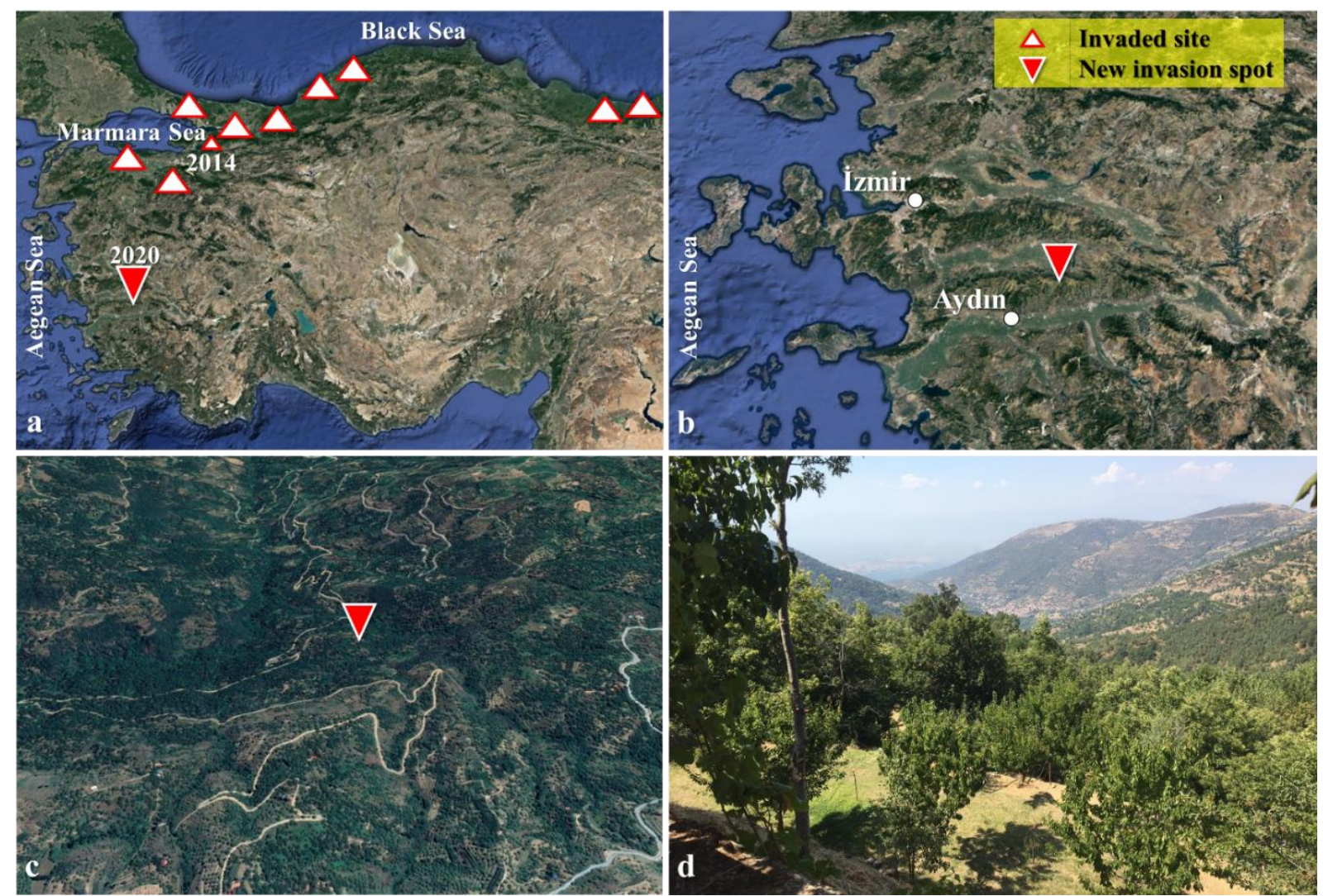

Figure 1. Invasion of the Asian chestnut gall wasp, Dryocosmus kuriphilus, in Turkey (a), and closer views of the study site in Ödemiș, İzmir (b-d) 


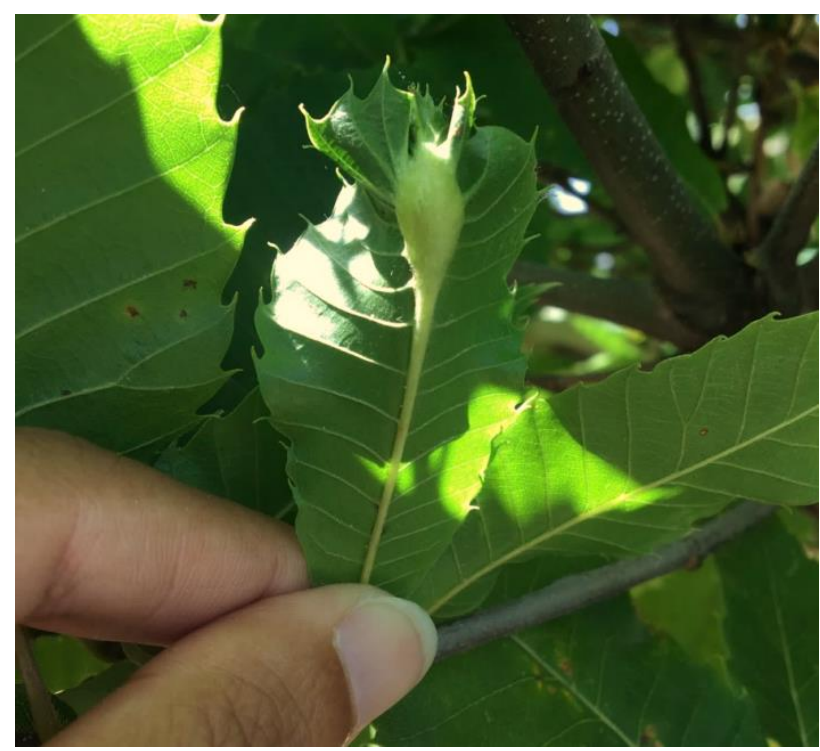

Figure 2. Dryocosmus kuriphilus leaf-gall on a chestnut tree in a private orchard in Ödemiş, İzmir

\section{Discussion and conclusions}

This study confirmed the presence of the Asian chestnut gall wasp in Aegean region of Turkey. The invasion by the pest will most likely be a major problem particularly in Aydın and İzmir provinces, where chestnut producers have already suffered significantly during the last 50 years. Private chestnut orchards in this region cover 10,600 ha, and annual chestnut production in 2019 was ca. 44,400 tons. There are also natural stands covering ca. 4,100 ha in the region (OGM, 2013). Since this region alone produces almost $60 \%$ of the chestnut harvest of the country (ÖCE, 2018), invasion by the pest will probably have a much greater socioeconomic impact than it had in Marmara region, along with impacts on the balance of the international chestnut market as most chestnut production in this region is exported. This new problem will inevitably increase the social and political pressure on the Ministry of Agriculture and Forestry. Therefore, detailed management plans are urgently needed from both the state and the private sector to deal with this new pressure in the near future. The Turkish General Directorate of Forestry (OGM) has released annually the specific parasitoid of Asian chestnut gall wasp, Torymus sinensis Kamijo (Hymenoptera: Torymidae), since 2015 in the Marmara region under the supervision of one of the authors of this paper (KI). After we detected the pest in İzmir, OGM began to establish a $T$. sinensis rearing facility in the region. In October 2020, KI trained the staff to be employed in this facility along with two other new facilities in Sakarya and Zonguldak (Black Sea region). The İzmir facility will be activated as soon as the Asian chestnut gall wasp population in the region reaches a size suitable for $T$. sinensis release which will probably occur within two years.

\section{Ackowledgements}

Authors thank to Mehmet Selçuk, owner of the chestnut orchard, where the observations were conducted, and to two anonymous reviewers of the earlier version of the manuscript.

\section{References}

Azmaz, M., Katılmıs, Y., 2020. New infestation of Asian chestnut gall wasp in Eastern Black Sea Region, Turkey: A potential threat to natural regional chestnut population. Acta Biologica Turcica, 33(4): 205-210.

Battisti, A., Benvegnu, I., Colombari, F., Haack, R.A., 2013. Invasion by the chestnut gall wasp in Italy causes significant yield loss in Castanea sativa nut production. Agricultural and Forest Entomology, 16(1): 75-79. doi: 10.1111/afe.12036.

Brussino, G., Bosio, G., Baudino, M., Giordano, R., Ramello, F., Melika, G., 2002. Pericoloso insetto esotico per il castagno europeo. Informatore Agrario, 58(37): 59-61.

Çetin, G., Orman, E., Polat, Z., 2014. First record of the oriental chestnut gall wasp, Dryocosmus kuriphilus Yasumatsu (Hymenoptera: Cynipidae) in Turkey. Bulletin of Plant Protection, 54(4): 303-309.

EPPO, 2005. Dryocosmus kuriphilus. EPPO Bulletin, 35: 422-424.

FAO, 2002. Inventory of Chestnut Research, Germplasm and References. Regional Office for Europe, Rome, Italy.

Graziosi, I., Santi, F., 2008. Chestnut gall wasp (Dryocosmus kuriphilus): Spreading in Italy and new records in Bologna province. Bulletin of Insectology, 61(2): 343-348.

İpekdal, K., Coşkuncu, K.S., Aytar, F., Doğanlar, M., 2014. Chestnut Gall Wasp Dryocosmus kuriphilus Yasumatsu (Hymenoptera: Cynipidae): An update for its situation on the world and in Turkey and its management. Türkiye Entomoloji Bülteni, 4(4): 241-257.

Mattoni, C., Matin, M.A., Pollegioni, P., Cherubini, M., Villani, F., 2013. Microsatellite markers reveal a strong geographical structure in European populations of Castanea sativa (Fagaceae): Evidence for multiple glacial refugia. American Journal of Botany, 100(5): 951-961.

OGM, 2013. Chestnut Action Plan 2013-2017. Orman Genel Müdürlüğü, Ankara (in Turkish).

ÖCE-Ödemis Commodity Exchange, 2018. Chestnut Sectoral Report, İzmir, https://www.otb.org.tr/dosyalar/sektorelraporlar/ kestane.pdf, Erişim: 10.11.2021

Rieske, L.K., 2007. Success of an exotic gallmaker, Dryocosmus kuriphilus, on chestnut in the USA: A historical account. EPPO Bulletin, 37: 172-174.

Villani, F., Pigliucci, M., Cherubini, M., 1994. Evolution of Castanea sativa Mill, in Turkey and Europe. Genetics Research, 63(2): 109-116.

Yıldız, Y., Yıldırım, İ., Albas, E., Bostancı, C., Aydoğan, O., 2020. İstilac1 tür kestane gal arıs1 (Dryocosmus kuriphilus) Yasumatsu (Hymenoptera: Cynipidae)'nin yeni yayılış alanları. Bartın Orman Fakültesi Dergisi, 22(3): 1014-1022. 